\title{
Aplicación del derecho a no autoincriminarse en procedimientos administrativos sancionatorios: Análisis comparado de la jurisprudencia del Tribunal Europeo de \\ Derechos Humanos y del Tribunal Constitucional chileno
}

\section{Application of the right against self-incrimination in administrative sanctioning proceedings: A Comparative Analysis of the Case Law of the European Court of Human Rights and the Chilean Constitutional Court}

El derecho a no autoincriminarse puede entenderse como el derecho de toda persona a guardar silencio y a no ser obligada a colaborar con una investigación en su contra. Una de las principales discusiones sobre este derecho dice relación con su campo de aplicación, en particular, sobre si es posible o no reconocer su vigencia en procedimientos administrativos sancionatorios. En otras palabras, ¿tienen las personas imputadas en procedimientos administrativos sancionatorios
The right against self-incrimination can be understood as the right of all persons to remain silent and not to be forced to collaborate with an investigation against them. One of the main discussions about this right is related to its field of application, especially regarding the question of whether it is possible or not to recognize its application in administrative sanctioning proceedings. In other words, do persons charged in administrative

\footnotetext{
* Abogado, Doctor en Derecho, Università Luigi Bocconi; Magister en Derecho Penal y Procesal Penal, Universidad Diego Portales; Profesor de Derecho Penal y Procesal Penal, Universidad Austral de Chile. Dirección postal: Los Pinos s/n, Balneario Pelluco, Puerto Montt, Chile. Correo electrónico: javier.escobar@mail.udp.cl. Código Orcid: 0000-0001-9266-0396.
}

Artículo recibido el 20 de octubre de 2021 y aceptado el 20 de diciembre de 2021. 
derecho a no autoincriminarse? El presente trabajo tiene por finalidad analizar, en clave comparada, la respuesta que el Tribunal Europeo de Derechos Humanos y el Tribunal Constitucional chileno han dado a la pregunta anterior, revisando la evolución y el estado actual de ambas jurisprudencias.

Palabras clave: Derecho a no autoincriminarse, derecho a guardar silencio, evidencia incriminatoria. sanctioning proceedings have the right against self-incrimination? This article aims to analyze, from a comparative perspective, the evolution and current state of the case law of the European Court of Human Rights and the Chilean Constitutional Court on this matter, in order to elucidate how these two courts have resolved the question posed.

Keywords: Right against self-incrimination, right to remain silent, incriminatory evidence.

\section{Introducción}

El problema de la aplicación de las garantías penales a infracciones y procedimientos administrativos sancionatorios se ha convertido en uno de los principales temas de discusión en materia sancionatoria. La antigua discusión en torno al fundamento y legitimidad de la potestad administrativa sancionatoria ha sido reemplazada por la forma en que dicha potestad debe ser ejercida'.

Una de las garantías penales cuyo campo de aplicación se discute es el derecho a no autoincriminarse. En términos generales, esta garantía puede entenderse como el derecho de toda persona a guardar silencio y a no ser obligada a colaborar con una investigación en su contra².

La importancia del derecho a no autoincriminarse ha sido universalmente reconocida. Por ejemplo, el Tribunal Europeo de Derechos Humanos (en adelante, TEDH) ha señalado que este derecho se encuentra en el corazón de la idea de un procedimiento justo ${ }^{3}$. Por su parte, la Corte Suprema estadounidense ha afirmado que el derecho a no autoincriminarse representa un avance fundamental en el desarrollo de las libertades de las personas, uno de los principales hitos en la lucha por construir una sociedad civilizada ${ }^{4}$. Por consiguiente, el reconocimiento del derecho a no autoincriminarse ha sido calificado como un acontecimiento histórico en la evolución del procedimiento penal angloamericano ${ }^{5}$.

A pesar de su fundamental importancia, y de la aparente simplicidad de su definición, el derecho a no autoincriminarse plantea diversas discusiones, tanto a nivel teórico como práctico ${ }^{6}$. En este sentido, se ha incluso afirmado que el derecho a no autoincriminarse es una de las garantías más complejas

\footnotetext{
CORDERO 2014, 400-401.

2 O'Halloran and Francis v. United Kingdom (2007), § 45.

3 John Murray v. United Kingdom (1996), § 45.

4 Ullman v. United States (1956), 426.

5 LANGBeIN 1994, 1047.

6 TRACZ 2019, 110.
} 
de aquellas aplicables en materia penal, existiendo debate incluso sobre su propia terminología?.

Una de las principales discusiones dice relación con la posibilidad de aplicar este derecho, tradicionalmente limitado al ámbito penal, a procedimientos administrativos sancionatorios. La relevancia de esta temática ha aumentado notablemente en las últimas décadas, debido al creciente número de procesos penales en que la autoridad competente utiliza evidencia obtenida en un procedimiento administrativo previo. El problema que estas situaciones plantean, a la luz del derecho a no autoincriminarse, es que en dichos procesos administrativos el imputado puede haber tenido obligación de declarar o colaborar con la autoridad, incluso bajo apercibimiento, circunstancia que permite cuestionar la voluntariedad de dicha colaboración ${ }^{8}$.

Para ejemplificar lo anterior, considérese el siguiente caso: La Comisión para el Mercado Financiero (CMF) inicia un procedimiento administrativo sancionatorio en contra de la dueña de una empresa, por haber infringido la prohibición de uso de información privilegiada, prevista en el artículo 165 de la Ley $N^{\circ}$ 18.045. En este contexto, la CMF cita a declarar tanto a la dueña de la empresa como a su gerente general. La primera persona ha sido citada en calidad de imputada, y la segunda en calidad de testigo. Supóngase que la gerente general también infringió la prohibición de uso de información privilegiada, pero la CMF no está en conocimiento de ello, de modo tal que el procedimiento administrativo sancionatorio no se dirige en su contra.

¿Pueden negarse la dueña y la gerente general de la empresa a responder las preguntas formuladas por la CMF, o están obligadas a ello? ¿Cambiaría la situación si, de manera paralela al procedimiento administrativo, el Ministerio Público ha iniciado una investigación penal en contra de ellas por los mismos hechos?

El presente trabajo tiene por finalidad analizar, en clave comparada, la forma en que el TEDH y el Tribunal Constitucional chileno (en adelante, TCC) han respondido las preguntas planteadas anteriormente. A través de este estudio comparado se intentará demostrar, por un lado, que la jurisprudencia europea ha desarrollado una interpretación amplia en relación al derecho a no autoincriminarse, mientras que, por otro lado, el TCC ha adoptado una postura excesivamente restrictiva. La postura desarrollada por el TCC, en mi opinión, no respeta el estándar mínimo de protección exigido por los tratados internacionales de derechos humanos, generando el riesgo, por consiguiente, de hacer incurrir a Chile en responsabilidad internacional. Lo anterior justifica la necesidad de revisar críticamente la jurisprudencia del TCC y plantear una interpretación alternativa sobre el campo de aplicación del derecho a no autoincriminarse.

\footnotetext{
7 Trechsel 2005, 341. Ver también Higgins 1977, 351.

8 HeRnÁNDEZ 2014, 582-583.
} 
La razón por la cual se ha escogido estudiar la jurisprudencia del TEDH y no, por ejemplo, la de la Corte Interamericana de Derechos Humanos, se debe a que el primero ha desarrollado una importante jurisprudencia sobre el problema de la aplicación del derecho a no autoincriminarse en procedimientos administrativos sancionatorios, pronunciando un número relevante de sentencias al respecto. Este no ha sido el caso de la Corte Interamericana de Derechos Humanos, la cual, por diversas razones, no ha tenido todavía oportunidad de construir una línea jurisprudencial sobre la materia en estudio.

Es menester tener presente que la metodología que se empleará en este artículo es de corte jurisprudencial y comparada. Esto significa que el objeto del presente trabajo se limita a analizar las dos jurisprudencias escogidas, a saber, la del TEDH y la del TCC. Con esto se busca evidenciar las diferencias existentes entre ambas aproximaciones, a fin de introducir en el debate jurídico nacional la existencia de posturas contrapuestas sobre el problema en estudio, promoviendo, de esta manera, la apertura de un debate sobre el campo de aplicación del derecho a no autoincriminarse. Como consecuencia de lo anterior, no se pretende, al menos no en esta oportunidad, ofrecer una respuesta definitiva a todos los problemas y desafíos que, a lo largo del trabajo, serán analizados.

Como último punto, resulta fundamental destacar que el objeto de este trabajo es independiente del debate nacional sobre el fundamento, límites y conveniencia de aplicar las garantías penales a las infracciones y procedimientos administrativos. Como bien se sabe, respecto de esta discusión existen actualmente dos posturas. La primera postura, defendida por el TCC, propugna que los principios inspiradores del orden penal contemplados en la Constitución han de aplicarse, por regla general y con matices, al derecho administrativo sancionatorio, puesto que ambos son manifestaciones del ius puniendi propio del Estado?. La segunda postura, en cambio, critica esta transferencia automática de principios y garantías desde el derecho penal al derecho administrativo sancionatorio, argumentando que la primera postura se fundaría en una idea incorrecta, como lo es la supuesta identidad ontológica entre sanción penal y sanción administrativa. Además, esta postura sostiene que la tesis de la transferencia ignoraría por completo los fines y las características propias del derecho administrativo sancionatorio, omisión que imposibilitaría construir una teoría razonable sobre esta rama del derecho. En consideración a lo anterior, esta segunda postura defiende que los principios y garantías del derecho administrativo sancionatorio deben desarrollarse precisamente a la luz de sus fines y características, pues solamente de esta manera se evitaría su desnaturalización ${ }^{10}$.

Como se señaló, la tesis que se planteará en este trabajo, en el sentido de que la actual jurisprudencia del TCC no respeta el estándar mínimo de

\footnotetext{
9 Sentencia TC Rol № 244-1996 (1996), c. $9^{\circ}$. Ver también sentencias Rol № 2682-2014 (2014), c. $11^{\circ} ; 2264-2012(2013)$, c. $33^{\circ} ; 479-2006(2006)$, c. $8^{\circ}$.

10 Ver, entre otros, SOto 2021; Letelier 2017; Aracena 2017.
} 
protección exigido por los tratados internacionales, no depende de la adopción de una de las dos posturas descritas en el párrafo anterior. En efecto, lo que aquí se pretende es dilucidar los alcances del derecho a no autoincriminarse, garantía que, como se explicará, proyecta su campo de aplicación más allá de los confines formales del sistema de justicia criminal. Esto en virtud de su propia estructura y fundamento, y no en atención a una supuesta identidad ontológica entre sanción penal y sanción administrativa.

\section{Evolución y estado actual de la jurisprudencia del TEDH sobre la aplicación del derecho a no autoincriminarse en procedimientos ad- ministrativos sancionatorios}

\section{Reconocimiento del derecho a no autoincriminarse como parte del debido proceso}

El derecho a no autoincriminarse goza actualmente de un reconocimiento explícito en el artículo 7 de la Directiva EU 2016/343, norma que obliga a los Estados miembros de la Unión Europea a asegurar el derecho a guardar silencio y a no autoincriminarse. Sin embargo, este no fue siempre el caso.

A diferencia de otros instrumentos internacionales, tales como el Pacto Internacional de Derechos Civiles y Políticos ${ }^{11}$, y la Convención Americana de Derechos Humanos ${ }^{12}$, la versión original de la Convención Europea de Derechos Humanos no contempló explícitamente el derecho a no autoincriminarse ${ }^{13}$.

Este derecho tampoco fue incorporado en alguno de los protocolos adicionales a la Convención Europea, que fueron aprobados con posterioridad a su entrada en vigencia. Con todo, se ha argumentado que el no haber incorporado de manera explícita el derecho a no autoincriminarse en alguno de los protocolos adicionales, particularmente en el número 7, no puede ser calificado como un descuido del legislador europeo, toda vez que existía un general entendimiento de que el derecho a no autoincriminarse estaba incluido en el derecho a un debido proceso, formando parte de este ${ }^{14}$. Esta ha sido, por lo demás, la postura del TEDH.

El TEDH reconoció el derecho a no autoincriminarse en su sentencia Funke v. France, de $1993^{15}$. En este caso, la autoridad aduanera sancionó a una persona investigada en un procedimiento administrativo, por haberse

\footnotetext{
11 Artículo 14.3, letra g): "3. Durante el proceso, toda persona acusada de un delito tendrá derecho, en plena igualdad, a las siguientes garantías mínimas: (...) g) A no ser obligada a declarar contra sí misma ni a confesarse culpable".

12 Artículo 8.2, letra g): "2. Toda persona inculpada de delito tiene derecho a que se presuma su inocencia mientras no se establezca legalmente su culpabilidad. Durante el proceso, toda persona tiene derecho, en plena igualdad, a las siguientes garantías mínimas: (...) g) derecho a no ser obligado a declarar contra sí mismo ni a declararse culpable".

13 BaLsamo 2018, 117.

14 TRECHSEL 2005, 340.

15 Berger 2007, 516.
} 
negado a entregar documentos relativos a operaciones financieras de interés. El imputado argumentó que la imposición de dicha sanción era contraria a su derecho a no autoincriminarse ${ }^{16}$. El TEDH observó que la autoridad había sancionado al imputado con la intención de obtener ciertos documentos que creía que existían, aunque no estaba segura de ello, documentos que supuestamente contenían información sobre eventuales delitos cometidos por el imputado. Al no poder obtenerlos por otros medios, la autoridad intentó obligar al imputado a que entregara los documentos, proceder que, en opinión del TEDH, resultaba contrario al derecho a no autoincriminarse ${ }^{17}$.

En Funke, el TEDH no abordó el fundamento del derecho a no autoincriminarse, su campo de aplicación, o sus orígenes, circunstancia que motivó que algunos autores caracterizaran la tesis del TEDH como breve y délfica ${ }^{18}$.

Esta omisión sería subsanada tres años más tarde, en la sentencia John Murray v. United Kingdom. En este caso, el imputado alegó que se había violado su derecho a no autoincriminarse, por cuanto la autoridad había valorado en su contra la circunstancia de que él había guardado silencio durante el proceso penal ${ }^{19}$. El TEDH comenzó su razonamiento sosteniendo que, a pesar de no encontrarse específicamente mencionado en el artículo 6 de la Convención Europea, norma que establece el derecho a un debido proceso, no existe ninguna duda de que el derecho a no autoincriminarse constituye un estándar internacional que se encuentra en el corazón de la noción de un proceso justo, razón por la cual debe entenderse que este derecho forma parte de las garantías establecidas en el artículo $6^{20}$. Esta es la actual interpretación del TEDH ${ }^{21}$.

En el mismo sentido se ha pronunciado el Tribunal de Justicia de la Unión Europea (en adelante, TJEU). En efecto, a pesar de que la Carta de Derechos Fundamentales de la Unión Europea no menciona explícitamente el derecho a no autoincriminarse, el TJEU no ha tenido problemas para reconocer su existencia.

En Orkem, un caso sobre libre competencia decidido en 1989, el TJEU resolvió que la autoridad europea de libre competencia no podía, mediante una solicitud de información, menoscabar el derecho a defensa de la empresa investigada en el respectivo procedimiento. Por consiguiente, el TJEU afirmó que no resultaba admisible que la autoridad de libre competencia

\footnotetext{
16 Funke v. France (1993), § 44.

17 Ibíd., § 44; Balsamo 2018, 118; Lock 2019, 2229.

18 AsHWORTH 2008, 753.

19 John Murray v. United Kingdom (1996), § 41.

20 Ibíd., § 45.

21 Bajić v. North Macedonia (2021), § 64; Chambaz v. Switzerland (2012), § 52; Brusco v. France (2010), § 44; Bykov v. Russia (2009), § 92; Weh v. Austria (2004), § 39; Allan v. United Kingdom (2002), § 50; Heaney and McGuinness v. Ireland (2000), § 40.
} 
obligase a una empresa a proporcionarle información que pudiera significar la admisión de una infracción cometida por ella22.

Con el transcurso de los años, la postura del TJEU se fue asimilando cada vez más a la del TEDH, hasta que ambas se identificaron completamente. Así, a principios de 2021, en su sentencia Consob, el TJEU citó explícitamente la postura del TEDH, en el sentido de que el derecho a no autoincriminarse forma parte del derecho a un debido proceso, y, por lo tanto, debe entenderse incorporado en los artículos 47 y 48 de la Carta de Derechos Fundamentales ${ }^{23}$.

La tesis desarrollada por el TEDH, en el sentido de que el derecho a no autoincriminarse forma parte del derecho a un debido proceso, encuentra apoyo en la jurisprudencia de la Corte Suprema estadounidense. En Boyd v. United States, la Corte Suprema afirmó categóricamente que el derecho a no autoincriminarse constituye uno de los principios generales en un sistema respetuoso de las libertades individuales ${ }^{24}$. Posteriormente, en Malloy v. Hogan, la Corte Suprema resolvió que el derecho a no autoincriminarse era directamente aplicable a los Estados a través de la Decimocuarta Enmienda, y no solamente al Gobierno Federal, por cuanto este derecho forma parte de la noción general de un debido proceso $^{25}$.

En conclusión, la jurisprudencia estable del TEDH es clara: El derecho a no autoincriminarse forma parte del derecho a un debido proceso. Lo anterior ha permitido su reconocimiento y desarrollo por parte del TEDH, a pesar no de encontrarse explícitamente mencionado en la Convención Europea de Derechos Humanos.

\section{Fundamento del derecho a no autoincriminarse según el TEDH}

El fundamento del derecho a no autoincriminarse ha sido objeto de una ardua discusión. Prueba de ello son las muy diversas tesis que se han elaborado al respecto.

Un primer grupo de autores postula que el fundamento del derecho en estudio consistiría en la protección de las personas inocentes. Dada la asimetría de poder entre el Estado y las personas imputadas en un proceso penal, el sistema debe procurar evitar que la autoridad abuse de su situación de superioridad. Uno de estos posibles abusos sería el ejercicio de coacción en contra de la persona imputada, para que esta confiese o colabore con la investigación. Desde este punto de vista, el derecho a no autoincriminarse se erige como un límite al poder del Estado, prohibiendo cualquier uso coac-

\footnotetext{
22 Orkem (1989), § 34-35; Balsamo 2018, 117-118.

23 Consob (2021), § 37-38; Hancox 2021, 231.

24 Boyd v. United States (1886), 631-632.

25 Malloy v. Hogan (1964), 6.
} 
ción en contra del acusado, evitando, de esta manera, posibles confesiones forzadas ${ }^{26}$.

Una segunda postura sostiene que la finalidad del derecho a no autoincriminarse no se limita a la protección de los inocentes, sino que consiste en preservar la integridad del sistema judicial, asegurando que siempre el Estado tenga el deber de probar su acusación, pues ni siquiera las personas culpables deben ser condenadas a menos que la autoridad "asuma toda la carga"27.

Finalmente, para otro sector de la doctrina, el fundamento del derecho en estudio se encontraría en la preocupación por la situación extrema de conflicto en que se coloca a la persona obligada a colaborar con una investigación en su contra. El derecho a no autoincriminarse buscaría evitar someter al imputado a la cruel necesidad de optar entre contribuir a su propia condena, mentir (lo que en algunos sistemas importa cometer un delito de perjurio, aunque se posea la calidad de imputado), o incurrir en desacato, situación que constituiría una suerte de tortura moral28.

¿Qué ha señalado el TEDH sobre esta materia? El TEDH ha sostenido reiteradamente que el fundamento del derecho a no autoincriminarse es proteger a las personas imputadas en un proceso penal del uso de coacción indebida por parte de las autoridades, evitando, de esta manera, errores judiciales ${ }^{29}$.

Además de lo anterior, el TEDH ha señalado que, dado que el derecho a no autoincriminarse exige que la autoridad intente probar los hechos de la acusación sin recurrir a evidencia obtenida mediante métodos que puedan coaccionar la voluntad de la persona imputada, este derecho estaría íntimamente relacionado con la presunción de inocencia ${ }^{30}$.

\section{Campo de aplicación del derecho a no autoincriminarse}

En relación al campo de aplicación del derecho a no autoincriminarse, es necesario considerar, en primer lugar, que existen distintos tipos de autoincriminación. Por ejemplo, existe la autoincriminación consciente y voluntaria, la autoincriminación inadvertida, y la autoincriminación forzada por la autori$\operatorname{dad}^{31}$. A este respecto, es fundamental tener presente que el derecho a no autoincriminarse no prohíbe la realización de declaraciones incriminatorias per se. Por el contrario, este derecho solamente protege a las personas en contra de la obtención de evidencia mediante la utilización de medios coactivos $^{32}$. En otras palabras, no existe un derecho a no ser testigo en contra de

\footnotetext{
26 Griswold 1955, 10-19; LORCA 2020, 302.

27 Tehan v. Shott (1966), 415.

28 Murphy v. Waterfront Comm'n (1964), 55; Hernández 2015, 240; Nogueira 1999, 328.

29 Bajić v. North Macedonia (2021), § 64; Saunders v. United Kingdom (1996), § 68-69; John Murray v. United Kingdom (1996), § 45; Bykov v. Russia (2009), § 92.

30 Saunders v. United Kingdom (1996), § 68; Weh v. Austria (2004), § 39; Balsamo 2018, 118.

31 Moyland y Sonsteng 1990, 267.

32 Ibrahim and Others v. United Kingdom (2016), § 267.
} 
uno mismo, sino que solamente un derecho a no ser forzado a ser testigo en contra de uno mismo ${ }^{33}$. Por consiguiente, lo que resulta contrario al derecho a no autoincriminarse es el uso de coacción, y no la mera existencia de una declaración incriminatoria. Lo anterior es evidente, por cuanto las personas pueden libremente renunciar a su derecho a guardar silencio ${ }^{34}$.

Para efectos de determinar si ha existido o no una violación del derecho a no autoincriminarse, el TEDH analiza especialmente la naturaleza y grado de la coacción empleada, la existencia de salvaguardias procesales, y el uso que la autoridad hace de la evidencia obtenida coactivamente ${ }^{35}$.

A través de su jurisprudencia, el TEDH ha identificado tres tipos de situaciones que representan un riesgo evidente desde el punto de vista del derecho a no autoincriminarse. En primer lugar, cuando se obliga a una persona imputada a declarar bajo la amenaza de imposición de sanciones. En este caso, existirá una violación del derecho a no autoincriminarse, ya sea que la persona amenazada acepte declarar en dichas condiciones, o que sea sancionada por haberse negado a colaborar. En segundo lugar, cuando la autoridad ejerce presión física o psicológica en contra de la persona imputada para obtener evidencia. Finalmente, el TEDH también ha apreciado una violación al derecho a no autoincriminarse cuando las autoridades utilizan subterfugios para obtener información que no fueron capaces de obtener durante el interrogatorio ${ }^{36}$.

¿Son las personas jurídicas titulares del derecho a no autoincriminarse? Como correctamente se ha observado, el TEDH nunca se ha pronunciado expresamente sobre la posibilidad de reconocer a las personas jurídicas un derecho a no autoincriminarse, pues todos los casos resueltos por este tribunal sobre el derecho mencionado han estado relacionados con personas natura$\operatorname{les}^{37}$. Sin perjuicio de lo anterior, se debe tener presente que la Directiva EU 2016/343, instrumento que reconoció explícitamente la presunción de inocencia y el derecho a no autoincriminarse, dispuso, en su artículo 2, que ella solamente se aplica a personas naturales imputadas en un proceso penal. De esta manera, el legislador europeo decidió excluir a las personas jurídicas del campo de aplicación de esta Directiva, circunstancia que podría representar la postura actualmente mayoritaria a nivel de la Unión Europea ${ }^{38}$.

¿Qué tipo de evidencia protege el derecho a no autoincriminarse? El TEDH ha sido claro en señalar que no resulta razonable limitar el derecho a no autoincriminarse a confesiones o declaraciones directamente inculpatorias. Por el contrario, lo esencial para este derecho es evitar que evidencia

\footnotetext{
33 Moyland y Sonsteng 1990, 267.

34 Ibrahim and Others v. United Kingdom (2016), § 267.

35 Jalloh v. Germany (2006), § 101; Allan v. United Kingdom (2002), § 44.

36 Ibrahim and Others v. United Kingdom (2016), § 267.

37 Hernández 2015, 220-222; LAMBerigts 2016, 38.

38 LAMBERIGTS 2016, 36.
} 
obtenida coactivamente sea incorporada en un proceso penal ${ }^{39}$. El TJEU se ha pronunciado en el mismo sentido, en su sentencia Consob ${ }^{40}$.

En términos similares, la Corte Suprema estadounidense ha afirmado que el derecho de las personas a no ser obligadas a declarar en su contra, reconocido en la Quinta Enmienda, no se encuentra limitado a confesiones efectuadas por la persona acusada en un proceso penal. Por el contrario, el objetivo del derecho es garantizar que una persona, independiente de su estatus y del procedimiento de que se trate, no sea obligada a prestar una declaración que pudiera incriminarla penalmente ${ }^{41}$.

En Saunders v. United Kingdom, la autoridad administrativa sospechaba que la adquisición de una empresa por parte de Guiness había involucrado la comisión de ciertas conductas ilícitas, circunstancia que motivó el inicio de una investigación. En este contexto, la autoridad administrativa, en virtud de sus facultades legales, exigió y obtuvo la comparecencia de diversas personas, quienes debieron responder las preguntas formuladas. De conformidad con la legislación nacional, si las personas citadas se hubieren rehusado a comparecer y a responder las preguntas formuladas, ellas podrían haber sido acusadas de desacato, y sancionadas con una multa o con una pena privativa de libertad de hasta dos años. El Ministerio Público, sobre la base de la información recabada en el proceso administrativo, inició un procedimiento penal en contra de varias personas que habían declarado ante la autoridad administrativa. En la audiencia de juicio oral, el Ministerio Público utilizó los registros de las entrevistas que los imputados habían dado en el proceso administrativo, dando lectura a sus respuestas ${ }^{42}$.

Considerando la forma en que el Ministerio Público había utilizado los registros de las entrevistas de los imputados, el TEDH concluyó que su intención había sido incriminarlos penalmente. El TEDH además observó que los imputados habían respondido las preguntas formuladas por la autoridad administrativa debido a la amenaza de sanciones, todo lo cual era contrario al derecho a no autoincriminarse ${ }^{43}$. Mismo razonamiento expuso el TEDH en I. J. L. v. United Kingdom ${ }^{44}$.

En conclusión, la cuestión a analizar no es el específico tipo de procedimiento en que se obtuvo la evidencia mediante coacción, sino que su eventual relevancia penal. Esta es la cuestión que se debe resolver a fin de determinar si ha existido o no una violación del derecho a no autoincriminarse. Por consiguiente, una persona citada a declarar en un procedimiento civil, laboral, o administrativo, puede negarse a responder una pregunta formulada en

\footnotetext{
39 Saunders v. United Kingdom (1996), § 71; Ibrahim and Others v. United Kingdom (2016), § 268.

40 Consob (2021), § 40.

41 Counselman v. Hitchcock (1891), 562; MoYLAND y SonSTENG 1990, 279-280.

42 Saunders v. United Kingdom (1996), § 70-72; AsHWORTH 2008, 755.

43 Saunders v. United Kingdom (1996), § 72-76.

44 I. J. L. and Others v. United Kingdom (2000), § 79-83.
} 
dicho proceso, si la respuesta a ella podría eventualmente ser utilizada en su contra en el contexto de un proceso penal| ${ }^{45}$, tal como ocurrió en Saunders v. United Kingdom.

Lo anterior es de toda lógica, por cuanto, si no fuere así, la autoridad podría burlar el derecho a no autoincriminarse simplemente obligando a las personas a declarar en un procedimiento civil, y luego utilizando dicha información en un posterior proceso penal en su contra.

En el mismo sentido se ha pronunciado la Corte Constitucional italiana, en su sentencia 84-2021, de fecha 30 de abril de 2021. En este caso, la Commissione Nazionale per le Società e la Borsa (en adelante, Consob) impuso al imputado dos sanciones pecuniarias, una por $€ 200.000$ y la otra por $€ 100.000$, por haber infringido la prohibición de uso de información privilegiada. Asimismo, la Consob sancionó al imputado con una multa de €50.000, por haber infringido el artículo 187 quindecies de la Ley del Mercado de Valores italiana, norma que sanciona a toda persona que no cumpla con los requerimientos del Banco de Italia y de la Consob, o no coopere con las funciones de supervisión de dichas autoridades, o retrase su ejercicio. Para estimar que había existido una infracción al artículo 187 quindecies, la Consob tuvo en cuenta, primero, que el imputado había solicitado y obtenido en múltiples ocasiones un aplazamiento de la fecha de la audiencia a la que había sido citado a declarar, y, segundo, que una vez celebrada la audiencia, el imputado se rehusó a responder las preguntas formuladas por la autoridad. En paralelo al procedimiento administrativo, el imputado fue acusado penalmente por el delito de uso de información privilegiada, sobre la base de los mismos hechos. En dicho proceso, el imputado acordó con el Ministerio Público una condena condicional de once meses de prisión y una multa de $€ 300.000$, sanción impuesta por el Tribunal de Milán mediante sentencia de fecha 08 de diciembre de $2013^{46}$.

En el procedimiento administrativo, el imputado impugnó las sanciones impuestas ante la Corte de Apelaciones de Roma, la que, sin embargo, desestimó el recurso. En contra de esta decisión, el imputado recurrió de casación ante la Corte Suprema italiana. Con fecha 16 de febrero de 2018, la Corte Suprema planteó una cuestión de constitucionalidad ante la Corte Constitucional italiana, cuestionando la legitimidad del artículo 187 quindecies, en la parte en que dicha norma podría ser aplicada también a la persona que está siendo actualmente siendo objeto de una investigación por la Consob, circunstancia que sería contraria, entre otros, al derecho a no autoincriminarse ${ }^{47}$.

\footnotetext{
45 A la misma conclusión arribó el Tribunal de Justicia de la Unión Europea, en su sentencia Consob (2021), § 44 .

46 Corte Constitucional de Italia, sentencia 84-2021, Ritenuto in fatto, 1.1.

47 Corte Constitucional de Italia, sentencia 84-2021, Ritenuto in fatto, 1.1-1.6.
} 
En su sentencia, la Corte Constitucional italiana afirmó compartir la interpretación que el TEDH y el TJEU han desarrollado sobre la aplicación del derecho a no autoincriminarse ${ }^{48}$. Por consiguiente, la Corte Constitucional sostuvo que sancionar a una persona investigada en un procedimiento administrativo de "naturaleza punitiva", carácter determinado conforme a los criterios Engel ${ }^{49}$, por rehusarse a responder las preguntas formuladas por la autoridad, si la respuesta a dichas preguntas podría importar su responsabilidad por una infracción administrativa de naturaleza penal o por un delito, era contrario al derecho a no autoincriminarse ${ }^{50}$.

Como consecuencia de lo anterior, la Corte Constitucional italiana resolvió declarar inconstitucional el artículo 187 quindecies, en la parte en que también podía aplicarse a una persona que se rehusaba a proporcionar a la Consob respuestas que pudieran importar su responsabilidad por una infracción administrativa de naturaleza punitiva o por un delito ${ }^{51}$.

\section{Derecho a no autoincriminarse y entrega de documentos}

¿Comprende el derecho a no incriminarse la entrega de documentos? ¿Puede el Estado exigirle a una persona imputada en un proceso penal, bajo amenaza de sanción, que entregue un documento en su poder?

La relevancia práctica de este problema es evidente, debido a la importancia y trascendencia que la prueba documental desempeña en nuestro sistema de justicia, así como a la circunstancia de que, actualmente, existen autoridades con amplios poderes para incautar evidencia documental, así como para exigir su entrega, tales como la autoridad tributaria o de libre competencia. Lamentablemente, la jurisprudencia del TEDH sobre este tema no ha sido prístina.

La primera vez que el TEDH abordó esta materia fue en Funke v. France. En dicho caso, el TEDH estimó que había existido una violación del derecho a no autoincriminarse, debido a que la autoridad aduanera había sancionado al imputado por haberse negado a entregar documentos relativos a ciertas operaciones financieras. Si bien el TEDH no afirmó explícitamente que el derecho a no autoincriminarse comprende la entrega forzada de documentos, lo cierto es que la autoridad aduanera había sancionado al imputado precisamente por negarse a entregar documentos.

La postura del TEDH habría aparentemente cambiado con la sentencia Saunders v. United Kingdom. En este caso, el TEDH sostuvo que, dado que el derecho a no autoincriminarse está primariamente relacionado con respetar la voluntad de la persona imputada a guardar silencio, este derecho no cubre evidencia que existe con independencia de la voluntad del imputado,

\footnotetext{
48 Corte Constitucional de Italia, sentencia 84-2021, Considerato in diritto, 3.5.

49 Infra I, 5.

50 Corte Constitucional de Italia, sentencia 84-2021, Considerato in diritto, 3.6.

51 Corte Constitucional de Italia, sentencia 84-2021, Considerato in diritto, 3.7.
} 
respecto de la cual la autoridad sí puede utilizar métodos coactivos para obtenerla. Tal es el caso, por ejemplo, de muestras de sangre, orina o ADN, o de documentos obtenidos a través de una orden de incautación ${ }^{52}$.

Desde un punto de vista abstracto, el planteamiento de la sentencia Saunders podría parecer claro. De hecho, este fue incorporado explícitamente en el artículo 7.3 de la Directiva EU 2016/343, conforme al cual, el ejercicio del derecho a no autoincriminarse no impedirá a las autoridades reunir la evidencia que pueda ser obtenida legalmente a través de métodos coactivos, y que tenga existencia con independencia de la voluntad de las personas imputadas $^{53}$.

Sin perjuicio de lo anterior, lo cierto es que los específicos alcances de la sentencia Saunders respecto a la entrega de documentos no son pacíficos. En efecto, una primera lectura podría sugerir que el TEDH modificó, en la sentencia Saunders, la interpretación había previamente desarrollado en Funke ${ }^{54}$. En efecto el TEDH habría resuelto en Saunders excluir del campo de aplicación del derecho a no autoincriminarse la entrega de documentos. Desde este punto de vista, se podría incluso considerar que Saunders habría dejado sin efecto la decisión de Funke.

Sin embargo, existe una lectura alternativa. Como ha sugerido Redmayne, Funke y Saunders podrían leerse en el sentido de que la cuestión decisiva consiste en determinar si el Estado, a través de medios coactivos, estaría exigiendo o no a la persona imputada cooperar activamente con la investigación, cuestión que se encontraría prohibida. De esta manera, dado que el Estado puede obtener muestras biológicas sin la cooperación activa del imputado, utilizando coacción si fuere necesario, ello no infringiría el derecho a no autoincriminarse. Lo mismo ocurre cuando el Estado, mediante una orden de entrada y registro, incauta documentos o evidencia del domicilio del imputado, de quien no se exige una cooperación activa. Por el contrario, cuando el Estado exige a la persona imputada que entregue documentos que tiene en su poder, amenazándola con la imposición de sanciones en caso de rehusarse a cumplir con el requerimiento, en dicho caso sí se está demandando de esta persona una cooperación activa con la investigación, cuestión prohibida por el derecho a no autoincriminarse. Esto fue exactamente lo que ocurrió en Funke, lo que permitiría explicar que el TEDH haya estimado, en dicha oportunidad, una violación del derecho en estudio ${ }^{55}$.

Esta lectura alternativa habría sido confirmada por el TEDH en sus sentencias J. B. v. Switzerland, de 2001, y Chambaz v. Switzerland, de 2012.

En J. B. v. Switzerland, la autoridad tributaria sancionó a la persona imputada en un procedimiento administrativo por negarse a entregar do-

\footnotetext{
52 Saunders v. United Kingdom (1996), § 69; BalSAMO 2018, 118.

53 Klip 2019, 14; LAMBERIGTS 2016, 429.

54 AsHWORTH 2008, 759.

55 Redmayne 2007, 214-215.
} 
cumentos e información relativa a sus ingresos patrimoniales. En relación al argumento del imputado, de que la imposición de tales sanciones había sido contraria a su derecho a no autoincriminarse, el TEDH observó que la autoridad tributaria había intentado, mediante la imposición de sanciones, obligar al imputado a entregar documentos relativos a sus operaciones financieras, proceder que, en opinión del TEDH, vulnera el derecho a no autoincriminarse, por cuanto se intenta obligar al imputado a cooperar activamente con la investigación en su contra. Resulta particularmente interesante que el TEDH, citando Saunders, sostuvo que el presente caso no involucraba evidencia cuya existencia era independiente de la voluntad del imputado, a pesar de que se trataba de documentos ${ }^{56}$.

Una década después de J.B. v. Switzerland, el TEDH publicó su sentencia Chambaz v. Switzerland, un caso que se fundaba en hechos de similar naturaleza. En Chambez v. Switzerland, la autoridad tributaria sancionó al imputado en un procedimiento administrativo por negarse a entregar documentos e información sobre sus ingresos y activos financieros, a fin de determinar los impuestos que debería haber pagado. En relación a una eventual infracción al derecho a no autoincriminarse, el TEDH observó que la autoridad, al imponer sanciones pecuniarias, había buscado presionar al imputado para que entregara documentos bancarios relativos a su patrimonio, todo ello con el propósito de determinar eventuales infracciones tributarias. Este proceder, en opinión del TEDH, vulneraba el derecho a no autoincriminarse ${ }^{57}$.

5. Concepto autónomo de materia penal: "Procedimientos administrativos de naturaleza punitiva"

Un completo entendimiento de la postura del TEDH sobre el derecho a no autoincriminarse presupone conocer su jurisprudencia sobre el concepto de materia penal. Lo anterior por cuanto, si bien el TEDH ha sostenido que el derecho a no autoincriminarse ampara solamente a las personas imputadas en un proceso penal, o que puedan ser imputadas en un proceso de dicha naturaleza, ello no significa que la aplicación de este derecho esté confinada al sistema formal de justicia criminal. Por el contrario, su aplicación dependerá del concepto de materia penal que adopte el tribunal.

Conforme a la jurisprudencia del TEDH, el concepto de materia penal tiene un significado autónomo, no siendo dependiente de la calificación jurídica efectuada por el derecho interno. De lo contrario, la aplicación de ciertas garantías quedaría entregada al arbitrio del legislador nacional ${ }^{58}$.

A fin de determinar la verdadera naturaleza de una infracción o de un procedimiento, el TEDH aplica tres criterios, establecidos en su sentencia Engel v. Netherlands, de 1976. Estos tres criterios, comúnmente conocidos

\footnotetext{
56 J.B. v. Switzerland (2001), § 66-68.

57 Chambez v. France (2012), § 53-58; LAMBERIGTS 2016, 431.

58 Serazin v. Croatia (2018), § 64; Glantz v. Finland (2014), § 48; Escobar 2021, 204.
} 
como criterios Engel, son los siguientes: (i) La calificación jurídica según el derecho interno; (ii) La verdadera naturaleza de la infracción, y (iii) La severidad de la pena que la persona imputada arriesga ${ }^{59}$.

Aplicando estos criterios, el TEDH ha adoptado una noción amplia de materia penal, la cual comprende no solamente sanciones penales en sentido estricto, sino que también sanciones administrativas con una finalidad punitiva, tales como el retiro de la licencia de conducir por 18 meses $^{60}$, un recargado tributario del $10 \%$ por no pago de impuestos ${ }^{61}$, una multa de 720 Marcos finlandeses ${ }^{62}$, y una multa de 60 Marcos alemanes $^{63}$, entre otras ${ }^{64}$.

En consecuencia, sobre la base de los criterios Engel, es perfectamente posible que, a efectos de determinar el campo de aplicación de las garantías penales, incluyendo el derecho a no autoincriminarse, una sanción o un procedimiento calificado como administrativo por el derecho nacional, sea calificado como penal por el TEDH.

El TJEU ha adoptado la misma postura, pues ha tomado los criterios Engel de la jurisprudencia del TEDH, y los ha aplicado con similar resultado. Así, por ejemplo, en sus sentencias Garlsson Real Estate, Di Puma y Consob, el TJEU calificó las multas administrativas impuestas por la autoridad italiana para el mercado financiero, ello en atención a la finalidad represiva que las multas impuestas por dicha autoridad persiguen, y su alto grado de severidad ${ }^{65}$.

La sentencia J.B. v. Switzerland ejemplifica de manera nítida cómo opera el razonamiento del TEDH. Como se señaló, en este caso el TEDH estimó que se había vulnerado el derecho a no autoincriminarse del imputado, porque la autoridad tributaria lo había sancionado por rehusarse a entregar, en el marco de un procedimiento administrativo por una eventual evasión tributaria, documentos relativos a sus ingresos patrimoniales ${ }^{66}$.

Lo interesante es que, en respuesta al argumento del imputado, el Estado sostuvo, como excepción preliminar, que el derecho a no autoincriminarse no aplicaba en el presente caso, toda vez que el procedimiento en cuestión no era de naturaleza penal, sino que administrativa ${ }^{67}$. Sobre este punto, el TEDH reafirmó que el concepto de materia penal tiene un significado autónomo, el cual debe determinarse conforme a los criterios Engel. Aplicando

\footnotetext{
59 Engel and Others v. Netherlands (1976), § 81-83. Ver también Velkov v. Bulgaria (2020), § 45; Boman v. Finland (2015), § 30; Jussila v. Finland (2006), § 30.

60 Nilsson v. Sweden (2005).

61 Jussila v. Finland (2006), § 37-38.

62 Ruotsalainen v. Finland (2009), § 47.

63 Öztürk v. Germany (1984), § 50-54.

64 Escobar 2021, 205.

65 Garlsson Real Estate (2018), § 34-35; Di puma (2018), § 38; Consob (2021), § 43. Sobre este punto, ver también Lo ScHIAvo 2018, 652-653.

66 Supra I, 4.

67 J. B. v. Switzerland (2001), § 43.
} 
estos criterios, el TEDH concluyó que el procedimiento tributario en cuestión era sustancialmente penal, por cuanto una de sus finalidades era sancionar al imputado e imponerle una multa por haber cometido una conducta ilícita. Por consiguiente, el TEDH sostuvo que el imputado sí estaba amparado por el derecho a no autoincriminarse ${ }^{68}$.

Si bien el concepto autónomo de materia penal desarrollado por el TEDH ha sido objeto de críticas ${ }^{69}$, lo relevante para efectos de este trabajo es demostrar que este concepto autónomo ha permitido extender la aplicación de las garantías penales más allá de los confines del sistema de justicia criminal. En efecto, a pesar de que, conforme a la postura del TEDH, el derecho a no autoincriminarse solamente ampara a las personas imputadas en un proceso penal, o que puedan ser imputadas en un proceso de dicha naturaleza, la aplicación de los criterios Engel ha tenido como consecuencia una ampliación sustantiva del campo de aplicación de las garantías penales, incluyendo el derecho a no autoincriminarse. Por consiguiente, este derecho no está confinado al sistema de justicia criminal, sino que también aplica a procedimientos administrativos de naturaleza punitiva.

\section{Evolución y estado actual de la jurisprudencia del TCC sobre la apli- cación del derecho a no autoincriminarse en procedimientos admi- nistrativos sancionatorios}

La jurisprudencia del TCC sobre el derecho a no autoincriminarse es notablemente distinta a la del TEDH, siendo posible apreciar importantes diferencias en diversos niveles. En particular, la interpretación que ha desarrollado el TCC se caracteriza por ser sensiblemente más restrictiva que aquella de la jurisprudencia europea. A continuación, se evidenciarán las principales diferencias entre una y otra jurisprudencia, procurando abordar las mismas temáticas que fueron revisadas en los acápites anteriores.

1. Reconocimiento del derecho a no autoincriminarse como un derecho asociado a la libertad personal y la seguridad individual

A diferencia de la Convención Europea, la Constitución chilena sí reconoce explícitamente el derecho a no autoincriminarse, en su artículo 19, número 7, letra f), norma que dispone: "f) En las causas criminales no se podrá obligar al imputado o acusado a que declare bajo juramento sobre hecho propio; tampoco podrán ser obligados a declarar en contra de este sus ascendientes, descendientes, cónyuge y demás personas que, según los casos y circunstancias, señale la ley".

Como consecuencia de lo anterior, el TCC no ha tenido ninguna dificultad para reconocer la existencia del derecho en estudio, por cuanto esta no

\footnotetext{
68 Ibíd., § 44-50; Berger 2006, 349.

69 Escobar 2021, 208-210; Bachmaier 2019, 307.
} 
ha sido objeto de debate. Sin embargo, la regulación constitucional plantea otro tipo de problemas.

Interpretando el artículo 19, número 7, letra f), el TCC ha sostenido que la aplicación del derecho a no autoincriminarse requiere la concurrencia de cuatro elementos: (i) Que se trate de un proceso penal; (ii) Que la obligación de declarar pese sobre la persona imputada en dicho proceso; (iii) Que la declaración se exija bajo juramento; y (iv) Que la declaración se refiera a hechos propios $^{70}$.

La interpretación desarrollada por el TCC está decisivamente influida por una peculiaridad de la regulación constitucional chilena, que establece el derecho a no autoincriminarse de manera separada del derecho a un debido proceso y las demás garantías procesales, asociándolo, en cambio, a la protección de la libertad personal y seguridad individual ${ }^{71}$.

Esta particular forma de regular el derecho a no autoincriminarse ha llevado al TCC a concluir que el constituyente chileno quiso reconocer esta garantía "en un procedimiento en particular y no como una garantía general de todo procedimiento, pues estas se encuentran en el numeral $3^{\circ}$ del artículo 19. Asimismo, su inclusión en el numeral $7^{\circ}$ del artículo 19, que versa sobre la libertad personal y la seguridad individual, dirige su aplicación a la tutela de ambas garantías, que por regla general pueden verse afectadas como resultado de una causa criminal"72.

En conclusión, para el TCC el derecho a no autoincriminarse no forma parte del derecho a un debido proceso, sino que constituye un derecho autónomo, asociado a la protección de la libertad personal y la seguridad individual. Por consiguiente, el derecho a no autoincriminarse estaría separado de la noción general de un procedimiento justo.

La postura del Tribunal Constitucional chileno se distancia, de esta manera, de la interpretación desarrollada por el TEDH, diferencia que no es en absoluto irrelevante, sino que proyecta sus efectos sobre el campo de aplicación que el TCC le reconoce a esta garantía, como se verá más adelante.

\section{Fundamento del derecho a no autoincriminarse según el TCC}

Sobre al fundamento del derecho a no autoincriminarse, el TEDH y el TCC han desarrollado interpretaciones similares.

Según se indicó, el TEDH ha señalado que la finalidad del derecho a no autoincriminarse es proteger a las personas imputadas en un proceso penal del uso de coacción indebida por parte de las autoridades, evitando así errores judiciales. El derecho a no autoincriminarse estaría, además, relacionado con la presunción de inocencia, al exigir que la autoridad pruebe los hechos

\footnotetext{
70 Sentencia TC Rol No 2936-2015 (2015), c. $11^{\circ}$.

71 HeRnÁNDEZ 2015, 237.

72 Sentencia TC Rol N²381-2012 (2012), c. $10^{\circ}$.
} 
de la acusación sin recurrir a evidencia obtenida mediante métodos que hayan coaccionado la voluntad del imputado ${ }^{73}$.

El TCC ha adoptado una postura similar a la del TEDH, relacionando el derecho a no autoincriminarse con la integridad del sistema judicial y la presunción de inocencia. En efecto, el TCC ha afirmado que el derecho a no autoincriminarse se basa en el derecho a defensa, y es una de las expresiones de la presunción de inocencia. En palabras del TCC, dado que todas las personas deben ser reputadas como inocentes, y considerando que "los términos en que se manifiestan las declaraciones al interior de un proceso penal" no son "siempre inteligibles para sus participantes", es necesario "que se reconozca su derecho a que no pueden ser obligados a declarar sobre hecho propio". Esta posición, que reconoce a la persona imputada como un sujeto de derechos, y no como un objeto, "vale por igual para todos los procedimientos penales vigentes en Chile" ${ }^{\prime 4}$.

\section{Campo de aplicación del derecho a no autoincriminarse}

Probablemente, la mayor diferencia entre la jurisprudencia del TEDH y la del TCC radica en el campo de aplicación que se le reconoce al derecho a no autoincriminarse.

En el caso del TEDH, el campo de aplicación de este derecho es amplio, incluyendo no solo declaraciones directamente inculpatorias vertidas en un proceso penal, sino que también evidencia obtenida coactivamente en un procedimiento distinto, pero que pudiera ser eventualmente utilizada en contra del imputado en un proceso penal. De esta manera, lo esencial para determinar si ha existido o no una violación del derecho a no autoincriminarse no es el específico tipo de procedimiento en que se obtuvo la evidencia mediante coacción, sino que la relevancia penal que dicha evidencia pudiera tener. Por consiguiente, una persona citada a declarar en un procedimiento civil puede negarse a responder una pregunta formulada en dicho proceso, si la respuesta a ella podría eventualmente ser utilizada en su contra en un proceso penal. Así fue resuelto en Saunders v. United Kingdom y I.J.L. v. United Kingdom $^{75}$.

La postura del TCC difiere marcadamente de la del TEDH. Según el TCC, el derecho a no autoincriminarse no forma parte del derecho general a un debido proceso, sino que se encuentra asociado a la protección de la libertad personal y la seguridad individual, estando confinado, por lo tanto, a los márgenes establecidos en el artículo 19, número 7, letra f). Como se señaló, conforme a la jurisprudencia del TCC, la aplicación de la prohibición constitucional exigiría cuatro requisitos: (i) Que se trate de un proceso penal;

\footnotetext{
${ }_{73}$ Supra I, 2.

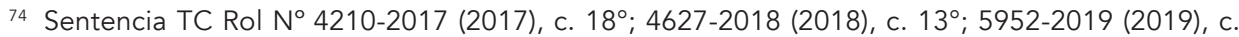
$14^{\circ} ; 3948-2017$ (2017), c. $12^{\circ}$.

75 Supra I, 3.
} 
(ii) Que la obligación de declarar pese sobre la persona imputada en dicho proceso; (iii) Que la declaración se exija bajo juramento; y (iv) Que la declaración se refiera a hechos propios ${ }^{76}$. La Constitución chilena reconocería el derecho a no autoincriminarse únicamente dentro de estos límites ${ }^{77}$. En otras palabras, la garantía en estudio beneficiaría solamente a quienes encuentran amenazada su libertad personal o su seguridad individual en el curso de una causa criminal78. Como consecuencia de lo anterior, la interpretación del TCC descarta cualquier posibilidad de reconocer a las personas jurídicas el derecho a no autoincriminarse, pues estas no pueden verse privadas de su libertad personal o seguridad individual, toda vez que, obviamente, no gozan de dichos derechos ${ }^{79}$.

Como consecuencia de lo anterior, no existiría una violación del derecho a no autoincriminarse si una persona imputada en un proceso penal fuese obligada a declarar, siempre que ello no tuviese lugar bajo juramento ${ }^{80}$. Asimismo, no existiría una violación al derecho a no autoincriminarse si una persona demandada en un procedimiento civil fuese obligada a declarar, sin importar que la respuesta a dichas preguntas pudiera significar su eventual responsabilidad penal por un delito cometido. Lo anterior permite afirmar que, en comparación a la regulación internacional, el reconocimiento constitucional del derecho a no autoincriminarse posee un alcance notablemente estrecho ${ }^{81}$, circunstancia que, por lo demás, ha sido reconocida por el propio TCC 82 .

¿Es posible extender la aplicación del derecho a no autoincriminarse a procedimientos no penales? Esta temática fue abordada por el TCC en su sentencia Rol 2381-2012. En este caso, la autoridad de libre competencia había citado a declarar al representante legal de una empresa investigada por supuestas conductas contrarias a la libre competencia. En ese contexto, la empresa presentó un requerimiento de inaplicabilidad por inconstitucionalidad de las normas que le imponían a dicha persona el deber de declarar bajo juramento, argumentando que ellas eran contrarias al derecho a no autoincriminarse.

Dado que el procedimiento en cuestión no era penal, sino que se trataba de una investigación llevada a cabo por la autoridad de libre competencia, la cuestión jurídica a resolver consistía en determinar si era posible o no extender a dicho proceso la aplicación del derecho a no autoincriminarse.

En primer lugar, el TCC sostuvo que la garantía reconocida en el artículo 19, número 7, letra f), no es aplicable a procedimientos jurisdiccionales no

\footnotetext{
76 Sentencia TC Rol No 5952-2019 (2019), c. 16; Rol No3948-2019 (2019), c. 14; Rol N 4627 2018 (2018), c. 15; Nogueira 1999, 326-328.

77 Sentencia TC Rol N² 2897-2015 (2015), c. $37^{\circ}$.

78 Sentencia TC Rol N 4210-2017 (2017), c. 18; 4627-2018 (2018), c. 13; 5952-2019 (2019), c. $14^{\circ}$; 3948-2017 (2017), C. $12^{\circ}$.

79 HeRnÁNDEZ 2015, 235-238.

80 CoRrea 2018, 254.

81 LORCA 2020, 304.

82 Sentencia TC Rol N² 2897-2015 (2015), c. 33 .
} 
criminales, "pues ella de modo explícito y con un propósito claro se refiere solo a las causas criminales" 83 . Por esta razón, el derecho a no autoincriminarse protege solamente a aquellas personas cuya libertad personal o su seguridad individual es amenazada en el curso de una causa criminal ${ }^{84}$.

Sin perjuicio de lo anterior, el TCC reconoce que, excepcionalmente, es posible extender la aplicación de garantías penales a procedimientos no penales, siempre que se respete el fundamento de cada garantía y su contenido esencial, ello con la finalidad de no "desfigurar el derecho hasta hacerlo irreconocible" 85 .

Ahora bien, ¿cuál es el contenido esencial del derecho a no autoincriminarse? A este respecto, el TCC afirma que la esencia de la garantía en cuestión, la cual no podría ser desvirtuada por una construcción jurisprudencial, consiste en la prohibición de forzar a una persona a declarar en su contra, en un procedimiento que amenace su libertad o seguridad individual ${ }^{86}$. Por consiguiente, "la garantía de no autoincriminación podría extenderse a otros procedimientos, cuando estos afecten la libertad personal o seguridad individual de una persona de un modo equiparable a la afectación derivada de causa criminal, y también podría cubrir supuestos en que la declaración no se exige bajo juramento"87. Como consecuencia de lo anterior, cuando dicha afectación no exista, o ella no sea asimilable a la que deriva de un proceso penal, no corresponderá aplicar el derecho a no autoincriminarse.

En el caso concreto, el TCC concluyó que no era posible reconocer dicha equiparación, toda vez que se trataba de un procedimiento de libre competencia, rechazando, por consiguiente, la aplicación del derecho a no autoincriminarse ${ }^{88}$.

Como se puede apreciar, el TCC ha desarrollado una interpretación decididamente restrictiva en relación al campo de aplicación del derecho en estudio, limitándolo a aquellos procesos que afecten la libertad personal o la seguridad individual del imputado de un modo equiparable a la afectación que deriva de una causa penal. Esta tesis está marcadamente influida por la peculiar regulación constitucional chilena, que explícitamente asocia el derecho a no autoincriminarse a la protección de la libertad personal y seguridad individual.

La postura desarrollada por el TCC permitiría que la autoridad, a fin de burlar el derecho a no autoincriminarse de una persona, la obligara a suministrar información de vital importancia en un procedimiento no penal, antecedentes que luego serán utilizados en un proceso penal en contra de

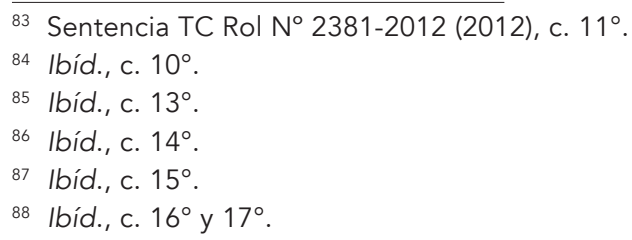


esa misma persona. Asimismo, tampoco existiría una infracción al derecho a no autoincriminarse si la autoridad tributaria, a fin de obligar a una persona investigada en sede administrativa a entregar documentos privados incriminatorios, decidiera imponerle sanciones pecuniarias. De esta forma, es perfectamente posible imaginar que si el TCC hubiese conocido los casos Saunders v. United Kingdom y I.J.L. v. United Kingdom, no habría apreciado una violación del derecho en estudio, a diferencia de lo resuelto por el TEDH.

Desde mi perspectiva, la excesivamente restrictiva interpretación del TCC sobre el derecho a no autoincriminarse no respeta el estándar mínimo de protección exigido por los tratados internacionales de derechos humanos, generando el riesgo, como consecuencia, de hacer incurrir a Chile en responsabilidad internacional. Por esta razón, el TCC debiese iniciar un proceso de reflexión crítica sobre su interpretación, buscando construir una aproximación más amplia que la actualmente vigente.

¿Cómo podría desarrollarse esta nueva interpretación? En mi opinión, la construcción de esta nueva interpretación solamente puede llevarse a cabo mediante el reconocimiento del derecho a no autoincriminarse como parte del derecho a un debido proceso, incorporándolo en las garantías procesales reconocidas en el número 3 del artículo 19 de la Constitución. De esta forma, la fuente positiva del derecho a no autoincriminarse no estaría ya exclusivamente limitada al artículo 19, número 7, letra f). Lo acá propuesto no representa una contradicción de lo dispuesto en esta última norma, pues, a mi entender, la regulación constitucional del número 7 del artículo 19 tuvo por objeto asegurar un estándar mínimo de protección constitucional a la fecha de entrada en vigencia de la Constitución. Dicho en otros términos, el constituyente habría querido asegurar que el derecho a no autoincriminarse no fuese desconocido en el específico ámbito regulado en dicha norma, mas no limitar la aplicación de este derecho exclusiva y absolutamente a tales supuestos.

Por consiguiente, si el TCC reconociera que el derecho a no autoincriminarse forma parte del derecho a un debido proceso, tal como lo han afirmado el TEDH, el TJEU, y la Corte Suprema estadounidense, sería posible ampliar razonablemente el campo de aplicación de esta garantía, más allá de los excesivamente restringidos confines del artículo 19, número 7 , brindando un estándar de protección mayor al actualmente vigente, en línea con la jurisprudencia internacional y comparada.

Si bien los contornos precisos de esta nueva interpretación podrán ciertamente ser objeto de debate, pareciera claro que ella debiese concebirse a la luz del fundamento de la garantía en estudio. En efecto, si el fundamento del derecho a no autoincriminarse es proteger a las personas del uso de coacción indebida por parte de las autoridades, evitando abusos y errores judiciales, no existiría ninguna razón para limitar este derecho a los confines del artículo 19, número 7. Por el contrario, el estándar mínimo de protección de este derecho consistiría en garantizar que una persona, independiente de 
su estatus y del procedimiento de que se trate, no sea obligada a suministrar información que pudiera incriminarla penalmente.

\section{Referencia a la jurisprudencia de la Contraloría General de la Repú- blica sobre la aplicación del derecho a no autoincriminarse en pro- cedimientos administrativos sancionatorios}

A fin de evidenciar lo restrictivo de la jurisprudencia del TCC sobre esta materia, podría resultar interesante revisar la jurisprudencia de la Contraloría General de la República (en adelante, CGR).

En un primer momento, la CGR adopto una aproximación restrictiva al derecho a no autoincriminarse, similar a la del TCC. Así, en 81351-2011, la CGR resolvió que este derecho solamente podía ser invocado en el contexto de un procedimiento penal, no siendo aplicable, por consiguiente, a los procedimientos administrativos.

Esta interpretación fue modificada por la CGR a finales del año 2014, en su Dictamen 94425-14. En este caso, la Policía de Investigaciones (en adelante, PDI) inició una investigación interna en contra de dos funcionarios por una supuesta infracción al principio de probidad administrativa. La PDI les imputaba a los funcionarios que, en cumplimiento de una comisión de servicio en el extranjero para indagar un supuesto delito de lavado de activos, habrían pernoctado en el inmueble de una persona involucrada en dicho procedimiento penal, en circunstancias que se les había otorgado viático. Por consiguiente, la PDI estimaba que parte de esos recursos públicos no habían sido empleados para los fines previstos, configurándose así un enriquecimiento indebido. Habiendo sido citados a declarar en la investigación interna, los funcionarios policiales se rehusaron a prestar declaración, contraviniendo lo dispuesto en el artículo 135 de la Ley $N^{\circ}$ 18.834, norma que impone a los funcionarios públicos la obligación de colaborar con las investigaciones disciplinarias. Los funcionarios policiales supeditaron el cumplimiento de esa obligación a la finalización de un proceso penal que, en paralelo a la investigación interna, el Ministerio Público estaba tramitando en su contra por los mismos hechos.

En relación al argumento de los funcionarios policiales, la CGR sostuvo que, si bien el funcionario público a quien se le atribuye alguna infracción tiene el deber de colaborar con el procedimiento administrativo, "tal obligación no puede estimarse infringida si el servidor se niega a declarar siendo objeto de un proceso penal (...), en la medida que ese proceso penal se encuentre en curso simultáneamente con el sumario; que en ambas instancias se investiguen los mismos hechos; que la investigación administrativa diga relación con hechos propios del deponente; que de la declaración ante el órgano público puedan derivarse antecedentes que comprometan negativamente la responsabilidad penal del declarante y que el funcionario no haya renunciado a su derecho a guardar silencio". De concurrir las condiciones anteriormente 
descritas, exigirle al funcionario dar cumplimiento a su obligación de colaborar con la investigación podría infringir su derecho a no autoincriminarse. Esta interpretación ha sido posteriormente confirmada por la CGR en los Dictámenes 20824-2016 y 8909-2017.

Como se puede apreciar, la CGR ha reconocido la vigencia del derecho a no autoincriminarse en procedimientos administrativos, siempre que se configuren las siguientes cuatro condiciones: (i) Que, en paralelo al sumario administrativo, se esté tramitando un proceso penal en contra del mismo funcionario; (ii) Que tanto el sumario administrativo como el proceso penal versen sobre los mismos hechos; (iii) Que la investigación administrativa diga relación con hechos propios del funcionario citado a declarar; y (iv) Que la declaración del funcionario pueda suministrar a la autoridad antecedentes que comprometan su responsabilidad penal. Concurriendo estos cuatro requisitos, el funcionario público podrá legítimamente rehusarse a declarar, invocando su derecho a no autoincriminarse.

La CGR ha desarrollado así una postura más amplia que la del TCC, pues no limita el campo de aplicación del derecho a no autoincriminarse a los confines del sistema de justicia criminal. Por el contrario, la CGR ha extendido el campo de aplicación de la garantía en estudio, comprendiendo, bajo ciertas condiciones, procedimientos administrativos.

Sin embargo, a pesar de que la interpretación de la CGR es más amplia que la del TCC, ella todavía no alcanza la misma extensión que la interpretación desarrollada por el TEDH. En particular, entre la postura de la CGR y la del TEDH existen dos importantes diferencias.

En primer lugar, la CGR requiere que exista un proceso penal que se esté tramitando de manera simultánea al procedimiento administrativo. Esta circunstancia limita, desde un punto de vista temporal, la aplicación del derecho a no autoincriminarse, por cuanto no sería posible, según la postura de la CGR, que un funcionario público investigado en un proceso administrativo invocase la garantía en estudio si aún no se ha iniciado un proceso penal en su contra. Esta consecuencia no parece razonable, toda vez que el proceso penal podría incluso iniciarse precisamente debido a la información que el funcionario investigado estará obligado a entregar en el proceso administrativo.

En segundo lugar, la CGR exige que el proceso administrativo y el proceso penal, cuya tramitación está teniendo lugar de manera simultánea, versen sobre los mismos hechos, exigencia que limita, esta vez desde un punto de vista material, la aplicación del derecho a no autoincriminarse. Esto significa que un funcionario público no podría invocar el derecho a no autoincriminarse, a pesar de estar siendo simultáneamente investigado tanto en sede administrativa como en sede penal, si ambos procedimientos abordan distintos hechos, con independencia de si las eventuales respuestas del funcionario pudiesen ser autoincriminatoria. Así, por ejemplo, si un funcionario público está siendo investigado en sede administrativa por el hecho " $A$ ", y 
en sede penal por el hecho " $\mathrm{B}$ ", dicho funcionario no podrá rehusarse a responder las preguntas formuladas en el sumario administrativo, sin importar que sus respuestas pudiesen suministrar información que luego la autoridad utilizará en su contra en el proceso penal. Nuevamente, esta consecuencia no parece razonable.

En mi opinión, la CGR debiese ampliar su interpretación, en el sentido de no exigir que el deponente en sede administrativa esté siendo simultáneamente investigado en un proceso penal, ni que este verse sobre los mismos hechos. No parece haber una diferencia sustantiva, desde el punto de vista del derecho a no autoincriminarse, entre el caso en que el proceso penal ya se encuentra en tramitación, y el caso en que el proceso penal será iniciado en un futuro próximo. Por el contrario, el estándar que debiese gobernar la aplicación del derecho a no incriminarse es aquel desarrollado por el TEDH: Una persona citada a declarar puede negarse a responder una pregunta formulada por la autoridad, si la respuesta a ella podría eventualmente ser utilizada en su contra en el contexto de un proceso penal.

\section{Conclusiones}

1. El derecho a no autoincriminarse puede ser entendido como el derecho de toda persona a guardar silencio, y a no ser obligada a colaborar con una investigación en su contra. Una de las principales discusiones sobre esta materia consiste en determinar si es posible o no aplicarla esta garantía, tradicionalmente limitada al ámbito penal, a procedimientos administrativos sancionatorios.

2. El presente trabajo ha tenido por objeto analizar, en clave comparada, la forma en que el TEDH y el TCC han abordado el problema descrito anteriormente. El estudio comparado de ambas jurisprudencias ha permitido demostrar, por un lado, que el TEDH ha desarrollado una interpretación amplia respecto al derecho a no autoincriminarse, mientras que, por otro lado, el TCC ha adoptado una postura restrictiva sobre este derecho, limitándolo a su mínima expresión.

3. Conforme a la jurisprudencia del TEDH, el derecho a no autoincriminarse tiene por finalidad proteger a las personas imputadas en un proceso penal del uso de coacción indebida por parte de las autoridades, evitando, de esta manera, errores judiciales.

En cuanto a su campo de aplicación el TEDH ha sostenido reiteradamente que este no se limita a la confesión de actos ilícitos por parte de la persona imputada en un proceso penal, o a declaraciones evidentemente incriminatorias, sino que también abarca información sobre cuestiones de hecho que la autoridad podrían utilizar posteriormente en un proceso penal en su contra. De esta manera, la cuestión a analizar, a fin de determinar la aplicación del derecho en estudio, no es el específico tipo de procedimiento en que se obtuvo la evidencia, sino que su eventual relevancia penal. Por consi- 
guiente, una persona citada a declarar en un procedimiento civil, laboral, o administrativo, puede negarse a responder una pregunta formulada en dicho proceso, si la respuesta a ella podría eventualmente ser utilizada en su contra en el contexto de un proceso penal.

El campo de aplicación del derecho a no autoincriminarse ha sido ulteriormente ampliado por aplicación del concepto autónomo de materia penal desarrollado por el TEDH, tesis que ha permitido extender la aplicación de las garantías penales más allá de los confines del sistema de justicia criminal. En efecto, la aplicación de los criterios Engel ha ampliado el concepto de materia penal, permitiendo calificar como de naturaleza penal diversas sanciones administrativas, tales como el retiro de la licencia de conducir por 18 meses, un recargado tributario del $10 \%$ por no pago de impuestos, y una multa de 720 Marcos finlandeses, entre otras.

4. En comparación con la postura del TEDH, la interpretación desarrollada por el TCC sobre el derecho a no autoincriminarse se caracteriza por ser decididamente más restrictiva, especialmente respecto a su campo de aplicación.

En efecto, interpretando el artículo 19, número 7, letra f), el TCC ha sostenido que la aplicación del derecho a no autoincriminarse requiere la concurrencia de cuatro elementos: (i) Que se trate de un proceso penal; (ii) Que la obligación de declarar pese sobre la persona imputada en dicho proceso; (iii) Que la declaración se exija bajo juramento; y (iv) Que la declaración se refiera a hechos propios.

Sobre la posibilidad de extender la aplicación de este derecho a procedimientos no penales, el TCC se ha pronunciado en términos sumamente limitados. En particular, el TCC ha sostenido que la garantía de no autoincriminación podría extenderse a otros procedimientos únicamente cuando estos afecten la libertad personal o la seguridad individual del imputado de un modo equiparable a la afectación que deriva de una causa criminal. Cuando tal afectación no exista, o ella no sea asimilable a la que deriva de un proceso penal, no será posible entonces reconocer la aplicación del derecho a no autoincriminarse. La tesis del TCC está marcadamente influida por la peculiar regulación constitucional chilena, que asocia el derecho a no autoincriminarse a la protección de la libertad personal y seguridad individual.

Como consecuencia de lo anterior, no existiría una violación del derecho a no autoincriminarse si una persona demandada en un procedimiento civil fuese obligada a declarar, sin importar que la respuesta a dichas preguntas pudiera significar su eventual responsabilidad penal por un delito cometido. Asimismo, tampoco existiría una infracción al derecho a no autoincriminarse si la autoridad tributaria, a fin de obligar a la persona investigada en sede administrativa a que entregue documentos privados incriminatorios, la sancionara monetariamente. Como se puede apreciar, la interpretación desarrollada por el TCC permitiría que la autoridad burlase fácilmente el derecho a no autoincriminarse de una persona imputada. 
5. Las consecuencias negativas descritas precedentemente no han sido suficientemente advertidas por parte del TCC, siendo necesario y urgente que el tribunal revise críticamente su actual jurisprudencia, a la luz del derecho internacional y comparado, desarrollando una interpretación alternativa.

A fin de construir esta interpretación alternativa, el TCC debiese reconocer que el derecho a no autoincriminarse como parte del derecho a un debido proceso, incorporándolo en las garantías procesales reconocidas en el número 3 del artículo 19 de la Constitución. De esta forma, la fuente positiva del derecho a no autoincriminarse no estaría ya exclusivamente limitada a lo dispuesto en el artículo 19, número 7, letra f). Este nuevo enfoque permitiría ampliar razonablemente el campo de aplicación de la garantía en estudio, más allá de los excesivamente restringidos confines del artículo 19, número 7, brindando un estándar de protección mayor al actualmente vigente, en línea con la jurisprudencia internacional y comparada.

Si bien los contornos precisos de esta nueva interpretación podrán ciertamente ser objeto de debate, pareciera claro que ella debiese concebirse a la luz del fundamento de la garantía en estudio. En efecto, si el fundamento del derecho a no autoincriminarse es proteger a las personas del uso de coacción indebida por parte de las autoridades, evitando abusos y errores judiciales, no existiría ninguna razón para limitar este derecho a los confines del artículo 19, número 7. Por el contrario, el estándar mínimo de protección de este derecho consistiría en garantizar que una persona, independiente de su estatus y del procedimiento de que se trate, no sea obligada a suministrar información que pudiera incriminarla penalmente.

\section{Bibliografía citada}

Aracena Salgado, Pedro (2017). Una interpretación alternativa a la justificación de garantías penales en el derecho administrativo sancionador para Chile, Revista de Estudios de la Justicia 26, 96-144.

AsHwORTH, Andrew (2008). Self-Incrimination in European Human Rights Law. A Pregnant Pragmatism, Cardozo Law Review 30(3), 751-774.

BACHMAIER, Lorena (2019). New Crime Control Scenarios and the Guarantees in Non-Criminal Sanctions: Presumption of Innocence, Fair Trial Rights, and the Protection of Property. En U. Sieber (Ed.), Prevention, Investigation, and Sanctioning of Economic Crime. Alternative Control Regimes and Human Rights Limitations (pp. 299-334). Maklu.

Balsamo, Antonio (2018). The Content of Fundamental Rights. En Roberto Kostoris [Ed.], Handbook of European Criminal Procedure (pp. 99-170). Springer.

Berger, Mark (2006). Europeanizing Self-Incrimination: The Right to Remain Silent in the European Court of Human Rights, Columbia Journal of European Law 12(2), 339-382.

Berger, Mark (2007). Self-Incrimination and the European Court of Human Rights: Procedural Issues in the Enforcement of the Right to Silence, European Human Rights Law Review 5, 514-533.

CORDERO, Eduardo (2014). Los principios que rigen la potestad sancionadora de la Administración en el derecho chileno, Revista de Derecho de la Pontificia Universidad Católica de Valparaíso XLII(1), 399-439.

Correa Robles, Carlos (2018). Valoración del silencio del imputado en el proceso penal. Derecho alemán y derecho chileno. Revista de Derecho (Valdivia) XXXI(2), 237-261. 
Escobar Veas, Javier (2021). Ne bis in idem y sistemas sancionatorios de vía múltiple: análisis crítico de la jurisprudencia del Tribunal Europeo de Derechos Humanos. En C. Cárdenas, J. L. Guzmán y T. Vargas (Coords.), XVI Jornadas chilenas de Derecho Penal y Ciencias Penales. En homenaje a sus fundadores (pp. 201-218). Tirant lo Blanch.

GrISwOLD, Erwin N. (1955). The Fifth Amendment Today, Harvard University Press.

Hancox, Emily (2021). The Right to Remain Silent in EU Law. Cambridge Law Journal 80(2), 228-231.

Hernandez Basualto, Héctor (2014). Actividad administrativa, procedimiento sancionatorio-administrativo y proceso penal: algunas necesidades de coordinación legal. En J. Arancibia y P. Alarcón (Coords.), Sanciones Administrativas. X Jornadas de Derecho Administrativo (pp. 567-586). Thomson Reuters.

HeRnÁndez BASUAlto, Héctor (2015). ¿Derecho de las personas jurídicas a no auto-incriminarse? Revista de Derecho de la Pontificia Universidad Católica de Valparaíso XLIV(1), 217-263.

HIGGINS, Georganne R. (1977). Business Records and the Fifth Amendment Right against Self-Incrimination. Ohio State Law Journal 38(2), 351-378.

KLIP, André (2019). Fair Trial Rights in the European Union: Reconciling Accused and Victims' Rights. En T. Rafaraci y R. Belfiore (Eds.), EU Criminal Justice Fundamental Rights, Transnational Proceedings and the European Public Prosecutor's Office (pp. 3-25). Springer.

Lamberigts, Stijn (2016). The Directive on the Presumption of Innocence. A Missed Opportunity for Legal Persons?, Eurocrim 1, 36-42.

LAmberigts, Stijn (2016). The Privilege against Self-Incrimination: A Chameleon of Criminal Procedure, New Journal of European Criminal Law 7(4), 418-438.

Langbein, John H. (1994). The Historical Origins of the Privilege Against Self-Incrimination at Common Law, Michigan Law Review 92(5), 1047-1085.

Letelier Wartenberg, Raúl (2017). Garantías penales y sanciones administrativas, Política Criminal 12 (24), 622-689.

Lo Schiavo, Gianni (2018). The principle of ne bis in idem and the application of criminal sanctions: of scope and restrictions. ECJ 20 March 2018, Case C-524/15, Luca Menci ECJ 20 March 2018, Case C-537/16, Garlsson Real Estate SA and Others v Commissione Nazionale per le Società e la Borsa (Consob) ECJ 20 March 2018, Joined Cases C-596/16 and C-597/16, Enzo Di Puma v Consob and Consob v Antonio Zecca. European Constitutional Law Review 14(3), 644-663. Cambridge University Press.

Lock, Tobias (2019). Article 48 CFR. En M. Kellerbauer, M. Klamert and J. Tomkin, The EU Treaties and the Charter of Fundamental Rights. A Commentary (pp. 2227-2230). Oxford University Press.

LoRCA FerReCCIO, Rocío (2020). Libertad personal y seguridad individual. En C. Salgado y P. Contreras (Eds.), Curso de Derechos Fundamentales (pp. 281-316). Tirant lo Blanch.

Moyland, Charles E. y Sonsteng, John (1990). Privilege against Compelled Self-Incrimination, William Mitchell Law Review 16(1), 249-308.

Nogueira AlcalA, Humberto (1999). El derecho a la libertad personal y a la seguridad individual en el ordenamiento jurídico chileno. lus et Praxis 5(1), 289-337.

REDMAYNE, Mike (2007). Rethinking the privilege against self-incrimination, Oxford Journal of Legal Studies 27(2), 209-232.

Soto Delgado, Pablo (2021). El reproche personal en el Derecho Administrativo sancionador. Culpa y dolo, responsabilidad objetiva y culpa infraccional. Tirant lo Blanch.

TrACz, Eliot T. (2019). Doctrinal Evolution and the Right against Self-Incrimination, University of New Hampshire Law Review 18(1), 109-142.

TreChSEL, Stefan (2005). Human Rights in Criminal Proceedings. Oxford University Press.

\section{Normativa citada}

Constitución Política de la República de Chile [Const]. 17 de septiembre de 2005 (Chile).

Código Tributario [CT]. Decreto Ley Nº 830 de 1974. 31 de diciembre de 1974 (Chile).

Convención Europea de Derechos Humanos. Artículo 6. 4 de noviembre de 1950.

Convención Americana de Derechos Humanos. 22 de noviembre de 1969. 
Carta de Derechos Fundamentales de la Unión Europea. Artículos 47 y 48.07 de diciembre de 2000.

Directiva UE 2016/343 por la que se refuerzan en el proceso penal determinados aspectos de la presunción de inocencia y el derecho a estar presente en el juicio. Artículo 7. 09 de marzo de 2016.

Constitución de los Estados Unidos [Const.]. $5^{\text {a }}$ enmienda. 15 de diciembre de 1791 (Estados Unidos).

Constitución de los Estados Unidos [Const.]. 14 enmienda. 09 de julio de 1868 (Estados Unidos).

\section{Jurisprudencia citada}

Boyd v. United States. Caso No 116 U.S. 616. Juicio (1 de febrero de 1886).

Counselman v. Hitchcock 142 U.S. 547. Caso N 1020. Juicio (11 de enero de 1892).

Malloy v. Hogan. Caso No 378 U.S. 1. Juicio (15 de junio de 1964).

Ullman v. United States. Caso No 350 U.S. 422. Juicio (26 de marzo de 1956).

Murphy v. Waterfront Comm'n. Caso No 378 U.S. 52. Juicio (15 de junio de 1964).

Engel and Others v. Netherlands. Caso N 5100/71. Plenario. Parágrafo $81-83$ (8 de junio de 1976).

Orkem v Commission of the European Communities. Caso N C-374-87. Juicio. Parágrafo 31-35 (18 de octubre 1989).

Funke v. France. Caso No 10828/84. Juicio. Parágrafo 44 (25 de febrero de 1993).

John Murray v. United Kingdom. Caso N 18731/91. Juicio. Parágrafo 41 y 45 (8 de febrero de 1996).

Control de constitucionalidad del proyecto de ley, aprobado por el Congreso Nacional, enviado por la Cámara de Diputados y que modifica la Ley $N^{\circ} 4.601$, Ley de Caza, a fin de proteger la fauna: Tribunal Constitucional, 26 de agosto de 1996 (Rol N²44-1996).

Saunders v. United Kingdom. Caso No 19187/91. Juicio. Parágrafo 68-76 (17 de diciembre de 1996).

I. J. L. and Others v. United Kingdom. Caso No 3455/05. Juicio. Parágrafo 79-83 (19 de septiembre de 2000).

Heaney and McGuinness v. Ireland. Caso N 928. Juicio. Parágrafo 40 (21 de diciembre de 2000).

J. B. v. Switzerland. Caso No 31827/96. Juicio (3 de mayo de 2001).

Allan v. United Kingdom. Caso N 48539/99. Juicio. Parágrafo 44 y 50 (05 de noviembre de 2002).

Weh v. Austria. Caso N³8544/97. Juicio. Parágrafo 39 (8 de abril de 2004).

Jalloh v. Germany. Caso N 54810/00. Juicio. Parágrafo 97 y 101 (11 de julio de 2006).

Requerimiento de inaplicabilidad presentado por la Compañía Eléctrica San Isidro S. A. y otras, respecto del artículo 15 de la Ley No 18.410, Orgánica de la Superintendencia de Electricidad y Combustibles, en las causas caratuladas "Compañía Eléctrica San Isidro S. A. con Superintendencia de Electricidad y Combustibles", "Empresa Nacional de Electricidad S. A. con Superintendencia de Electricidad y Combustibles", "Empresa Eléctrica Pehuenche S. A. con Superintendencia de Electricidad y Combustibles" y "Empresa Eléctrica Pangue S. A. con Superintendencia de Electricidad y Combustibles", roles 5782-2004, 5783-2004, 5784-2004 y 5785-2004 respectivamente, todas seguidas ante la Corte de Apelaciones de Santiago: Tribunal Constitucional, 8 de agosto de 2006 (Rol No 479-2006).

Jussila v. Finland. Caso No 73053/01. Juicio. Parágrafo 30, 37-38 (23 de noviembre de 2006).

Bykov v. Russia. Caso No 4378/02. Juicio. Parágrafo 92 (10 de marzo de 2009).

Brusco v. France. Caso No 1466/07. Juicio criminal. Parágrafo 44 (14 de octubre de 2010).

Dictamen 81351-11 [Contraloría General de la República]. PDI recurso de reclamación baja por conducta mala. 29 de diciembre de 2011.

Chambaz v. Switzerland. Caso No 11663/04. Juicio (5 de abril de 2012). 
Requerimiento de inaplicabilidad por inconstitucionalidad presentado por Empresas Ariztía S.A. respecto del artículo 29 del Decreto Ley $N^{\circ} 211$, de 1973, en cuanto permite la aplicación del artículo 385 del Código de Procedimiento Civil, en los autos caratulados "Requerimiento de la FNE contra Agrícola Agrosuper S.A. y otros", de que conoce el Tribunal de Defensa de la Libre Competencia, bajo el Rol C N²36-11 (2013): Tribunal Constitucional, 20 de agosto de 2013 (Rol No 2381-2012). Segunda Sala. [Requerimiento de inaplicabilidad por inconstitucionalidad].

Requerimiento de inaplicabilidad por inconstitucionalidad presentado por CGE Distribución S.A. respecto del artículo 15, inciso primero, de la Ley $N^{\circ} 18.410$, que crea la Superintendencia de Electricidad y Combustibles, en los autos sobre reclamación de ilegalidad, caratulados "CGE Distribución S.A. con Superintendencia de Electricidad y Combustibles", de que conoce la Corte de Apelaciones de Santiago, bajo el Rol $N^{\circ}$ 4322-2012: Tribunal Constitucional, 10 de octubre de 2013 (Rol No 2264-2012).

Requerimiento de inaplicabilidad por inconstitucionalidad presentado por Aldo Motta Camp respecto del precepto legal contenido en el inciso segundo del artículo 35 de la Ley $N^{\circ} 19.880$, en aquella parte que dispone "cuando a la Administración no le consten los hechos alegados por los interesados o la naturaleza del procedimiento lo exija", en los autos caratulados "Motta Camp Aldo con Superintendencia de Valores y Seguros", sobre reclamo de ilegalidad de que conoce la Corte de Apelaciones de Santiago, bajo el Rol $N^{\circ}$ Civil-4359-2014: Tribunal Constitucional, 30 de octubre de 2014 (Rol No 2682-2014).

Glantz v. Finland. Caso No 38394/11. Juicio. Parágrafo 48 (20 de mayo de 2014). Dictamen 94425-14 [Contraloría General de la República]. Sobre denuncia de supuestas irregularidades en que habría incurrido la Policía de Investigaciones de Chile a propósito de una investigación interna. 4 de diciembre de 2014.

Boman v. Finland. Caso N 41604/11. Juicio. Parágrafo 30 (17 de febrero de 2015).

Ibrahim and Others v. United Kingdom. Caso No 50541/08, 50571/08, 50573/08, 40351/09. Juicio. Parágrafo 267 (13 de septiembre de 2016).

Requerimiento de inaplicabilidad por inconstitucionalidad presentado por Juvenal Gómez Gómez respecto del artículo 195 bis, inciso primero de la Ley N¹8.290, Ley de Tránsito, en los autos sobre delitos de conducción en estado de ebriedad con resultado de daños y negarse a la realización de alcoholemia, RIT No 1841-2015, RUC No 1510027986-7 del Juzgado de Garantía de Castro (2016): Tribunal Constitucional, 20 de octubre de 2016 (Rol N²936-2015). Segunda Sala. [Requerimiento de inaplicabilidad por inconstitucionalidad].

Dictamen 20824-16 [Contraloría General de la República]. Procede separación y baja por mala conducta de funcionarios de la Policía de Investigaciones de Chile, por encontrarse acreditada sus responsabilidades en los hechos indagados. 17 de marzo de 2016.

Dictamen 8909-17 [Contraloría General de la República]. Desestima recurso de reclamación, en atención a que la responsabilidad administrativa derivada de la conducta de funcionario de la Policía de Investigaciones de Chile en el hecho que indica se encuentra comprobada. 15 de marzo de 2017.

Requerimiento de inaplicabilidad por inconstitucionalidad respecto de los artículos 195, 196 bis y 196 ter de la Ley No 18.290, modificada por la Ley $N^{\circ} 20.770$, en el marco de los autos penales Rit 1479-2015, RUC 1500116832-8 del $9^{\circ}$ Juzgado de Garantía de Santiago (2017): Tribunal Constitucional, 04 de julio de 2017 (Rol No 2897-2015). Segunda Sala. [Requerimiento de inaplicabilidad por inconstitucionalidad].

Menci. Caso N C-524-15. Juicio penal (20 de marzo de 2018).

Garlsson Real Estate SA and Others v Commissione Nazionale per le Società e la Borsa (Consob). Caso N C-537-16. Juicio (20 de marzo de 2018).

Enzo Di Puma v Commissione Nazionale per le Società e la Borsa (Consob) and Commissione Nazionale per le Società e la Borsa (Consob) v Antonio Zecca. Caso N C-596-16. Juicio (20 de marzo de 2018).

Serazin v. Croatia. Caso No 19120/15. Juicio. Parágrafo 64 (9 de octubre de 2018).

Requerimiento de inaplicabilidad por inconstitucionalidad presentado por Carlos Arturo Durán Low respecto de los artículos 478, 481, 482 y 488, todos del Código de Procedi- 
miento Penal, en la gestión pendiente en el proceso penal sustanciado por el Ministro en Visita Extraordinaria don Mario Carroza Espinosa, en actual conocimiento de la Corte de Apelaciones de Santiago, por recursos de casación en la forma y apelación, bajo el Rol No 351-2016 (2018): Tribunal Constitucional, 11 de diciembre de 2018 (Rol N $4627-$ 2018). Segunda Sala. [Requerimiento de inaplicabilidad por inconstitucionalidad].

Requerimiento de inaplicabilidad por inconstitucionalidad presentado por Guido Hermes Riquelme Andaur respecto de los artículos 110, inciso segundo, 111, 318, 322, 351, inciso primero, 481, 485, 486, y 488 del Código de Procedimiento Penal, en el proceso Rol No 345-2017, seguido ante el Ministro en Visita Extraordinaria Mario Carroza Espinosa, en actual conocimiento de la Corte de Apelaciones de Santiago, por recursos de casación en la forma y apelación, bajo el Rol No 1068-2017: Tribunal Constitucional, 22 de enero de 2019 (Rol N 4210-2017). Segunda Sala. [Requerimiento de inaplicabilidad por inconstitucionalidad].

Requerimiento de inaplicabilidad por inconstitucionalidad presentado por Orlando Carter Cuadra respecto de los artículos 193, 205, 318, 330, inciso primero, 334, 481 y 482, del Código de Procedimiento Penal, en el proceso seguido ante el Ministro en Visita Extraordinaria Mario Carroza Espinosa, en actual conocimiento de la Corte de Apelaciones de Santiago, por recursos de casación en la forma y apelación, bajo el Rol No 9032017 (2019): Tribunal Constitucional, 2 de mayo de 2019 (Rol No 3948-2019). Primera Sala. [Requerimiento de inaplicabilidad por inconstitucionalidad].

Requerimiento de inaplicabilidad por inconstitucionalidad presentado por Manuel Arturo Montero Souper respecto de los artículos 481, 482, 483, 484, 485, 486, 487, y 488, todos, del Código de Procedimiento Penal, en el proceso penal seguido ante el Ministro en Visita Extraordinaria de la Corte de Apelaciones de Temuco, Álvaro Mesa Latorre, bajo el Rol No 63.556 del ingreso criminal del Juzgado de Letras de Angol, por el delito de homicidio calificado de Oscar Armando Gutiérrez Gutiérrez (2019): Tribunal Constitucional, 08 de agosto de 2019 (Rol No 5952-2019). Segunda Sala. [Requerimiento de inaplicabilidad por inconstitucionalidad].

Velkov v. Bulgaria. Caso No 34503/10. Juicio. Parágrafo (21 de julio de 2020).

$D B$ vs. Commissione Nazionale per le Società e la Borsa (Consob). Caso N ${ }^{\circ}$ C-481-19. Juicio (2 de febrero de 2021).

Bajić v. North Macedonia. Caso No 2833/13. Juicio (10 de junio de 2021).

Sentencia 84-2021, depositada con fecha 30 de abril de 2021. 